\title{
TEST OF COMPLEX NANOSTRUCTURES AS GENE DELIVERY SYSTEM TO CARDIAC CELLS
}

\author{
Josef SKOPALIK ${ }^{1,2}$, Jaroslav PRUCHA ${ }^{3,4}$, Jiri SEKORA², Vratislav CMIEL², Tomas PARAK ${ }^{1}$, \\ Josef MASEK $K^{5,6}$ \\ ${ }^{1}$ Department of Pharmacology and Toxicology, Faculty of Pharmacy, Masaryk University, Brno, \\ Czech Republic, EU, j.skopalik@gmail.com \\ ${ }^{2}$ Department of Biomedical Engineering, Faculty of Electrical Engineering and Communication, Brno \\ University of Technology, Brno, Czech Republic, EU \\ ${ }^{3}$ Department of Health Care Disciplines and Population Protection, Faculty of Biomedical \\ Engineering, Czech Technical University in Prague, Prague, Czech Republic, EU \\ ${ }^{4}$ Department of Information and Communication Technologies in Medicine, Faculty of Biomedical \\ Engineering, Czech Technical University, Prague, Czech Republic, EU \\ ${ }^{5}$ Centre of Experimental Medicine, Slovak Academy of Sciences, Bratislava, Slovakia, EU \\ ${ }^{6}$ Department of Pharmacology and Toxicology, Veterinary Research Institute, Brno, Czech Republic, EU
}

https://doi.org/10.37904/nanocon.2020.3757

\begin{abstract}
Various nanostructures, including liposomes, dendrimers, polymers, carbon or silicon materials, and metal nanoparticles seems to be evaluated as carriers in different gene delivery systems. Muscle cells are target of modern gene medicine, due to of the much pathology (arrhythmias, channels pathological mutation, abnormal apoptosis) with limited curability by traditional drugs. The zeta potential of the muscle cells were identified by non-traditional method of DLS. This was starting point to setting of parameters for experimental liposome, the liposome surface charge have been tested and modified by cationic plasmid and final complex was evaluated as delivery system of DNA into the muscle cardiac cells.
\end{abstract}

Keywords: Nanoliposom, nanoparticle, transfection, zeta potential, cell engineering, regenerative medicine

\section{INTRODUCTION}

The zeta potential of the cells and the zeta potentials of the modern "Trojan horse particles" (liposomes, exosomes, nanoparticles) are two key parameters, which must be tested to ideal compatibility, if there is the aim of the maximal effectivity of "Trojan soldiers“ homing into the living cells. The DLS technique was previously applied primarily in order to study microorganisms, cancer cells or blood cells $[1,2]$. We used a Zetasizer Nano ZS analyser to analyse the zeta potential of cardiomyocytes and also for characterisation of nanoparticles/nanoliposomes conjugated with GFP vector, which can be used s delivery system into the muscle and another type of mammalian cells. The analysis was correlated also with tests based on electrophoresis methods. Transfection of the cells and gen/protein delivery is the modern direction of the experimental medicine, however precise description of this phenomenon and developing of new "nano-entities“ need precise analysis of the surface charge and precise analysis of the interaction between cells and selected "Trojan particles".

\section{METHODS}

\subsection{Preparation of two types of cardiac cells}

Neonatal rat cardiomyocytes were isolated from Wistar 2-5 days old Neonatal rats. Hearts were removed and dissociated in a balanced salt solution containing $20 \mathrm{mM}$ HEPES, $120 \mathrm{mM} \mathrm{NaCl}, 1 \mathrm{mM} \mathrm{NaH} \mathrm{PO}_{4}, 5.5 \mathrm{mM}$ 
glucose, $5.4 \mathrm{mM} \mathrm{KCl}$, and $0.8 \mathrm{mM} \mathrm{MgSO}_{4}(\mathrm{pH}$ 7.3-7.4). Cardiomyocytes from the tissue homogenates were isolated by trypsin digestion, selection of cardiomyocytes were done using adhesive affinity to collagen bottom described in our previous experiments [3]. The cardiomyocytes cultures were suspended in DMEM and transferred (1000 cells/ $100 \mu \mathrm{L}$ ) to 96 well culture chamber plates, which was rewarmed to $37^{\circ} \mathrm{C}$. The first part of the cell culture was resuspendend and immediately taken from the bottom of plastic chamber and used for Zetasizer measurement of surface charge (chapter 2.2). The second part of the cells was incubated in DMEM medium and used for transfection tests (chapter 2.4) on microscopic unit.

Adult rat cardiomyocytes were obtained from young adult Wistar rats $(250 \pm 50 \mathrm{~g})$. The cardiomyocytes were isolated using the method of enzymatic dissociation via [4] (the heart was perfused with $\mathrm{Ca}^{2+}$ free Tyrode's solution containing collagenase, the final dissociated cardiomyocytes were collected in $\mathrm{Ca}^{2+}$ free Tyrode's solution and gently mixed with standard Tyrode's solution $\left(0.09 \mathrm{mmol} / / \mathrm{CaCl}_{2}\right)$ and diluted 1:1 byDMEM medium in 96 well chamber in following 30 minutes. The first part of the cell culture were resuspendend from the bottom of plastic chamber after 10 minutes and used for Zetasizer measurement of surface charge (chapter 2.2). The second part of the cells was used for transfection tests (chapter 2.4). All experiments underwent under improvement of ethics committee.

\subsection{The cell surface charge identification by Zetasizer}

The zeta potential of the cells was recorded in a suspension $\left(0.3 \times 10^{6} \mathrm{cells} / \mathrm{ml}\right)$ using the electrophoretic light scattering technique on a Zetasizer Nano ZS analyser (Malvern Instruments, Great Britain). The measurements were performed in a U-shaped cell with gold-plated electrodes at $25^{\circ} \mathrm{C}$ or $37^{\circ} \mathrm{C}$.

\subsection{The nanoparticle and lipid vesicle selection and their surface charge identification}

Nano-liposomes (NL) were prepared by hydration of phospholipid film method composed of $\mathrm{N}-[1-(2,3-$ Dioleoyloxy)propyl]-N,N,N-trimethylammonium methyl-sulphate (DOTAP) and 1,2-Dioleoyl-sn-Glycero-3Phosphoethanolamine (DOPE) [1]. The suspension was extruded through polycarbonate filters (pore size of $100 \mathrm{~nm}$ ). Resultant liposomes were mixed with plasmid pcDNA4/TO-bio-myc-NES-EGFP to form lipid-DNA complexes, three variants of concentration were used (details in Results, Figure 2).

Maghemite nanoparticles (FeNP) were synthesized by borohydride reduction ( $53 \mathrm{mmol}$ in liquid ammonia) of ferric chloride $\mathrm{FeCl}_{3} \cdot 6 \mathrm{H}_{2} \mathrm{O}$ (37 mmol), both purchased from Sigma-Aldrich Co. (St Louis, MO, USA), at room temperature. After the reduction reaction (indicated by change of colour to black), the temperature of the mixture was increased to $100^{\circ} \mathrm{C}$ and held constant for 2 hours. After cooling the mixture to room temperature, the magnetic fraction was separated using an external magnet and washed several times with water. Details in [5].

The surface of the liposomes or nanoparticles was modified by addition of plasmid pcDNA4/TO-bio-myc-NESEGFP to form final DNA-particle of DNA-liposome complexes. Conjugation was tested with three different concentration of plasmid (10 $\mu \mathrm{g} / \mu \mathrm{L}, 20 \mu \mathrm{g} / \mu \mathrm{L}, 40 \mu \mathrm{g} / \mu \mathrm{L}$ ) in conjugation solution (timing and temperature described in Results) and after the conjugation step the electrophoresis was used for quantitative detection of amount of free (non bound) plasmid and relative effectivity of plasmid binding (details in Results).

\section{RESULTS}

\subsection{The cell surface charge identification by Zetasizer}

The zeta potential of cardiomyocytes in DMEM medium was measured under $25^{\circ} \mathrm{C}$ or $37^{\circ} \mathrm{C}$ respectively; all variants are reprinted in the following Table 1. 
Table 2 Cell samples measurement by Zetasizer

\begin{tabular}{|l|l|l|}
\hline Sample variant & Temperature $25^{\circ} \mathrm{C}$ & Temperature $37^{\circ} \mathrm{C}$ \\
\hline Neonatal cardiomyocytes & $-9,60 \mathrm{mV}$ & $-9,1 \mathrm{mV}$ \\
\hline Adult cardiomyocytes & $-10,77 \mathrm{mV}$ & $-14,24 \mathrm{mV}$ \\
\hline
\end{tabular}

\subsection{The nano-complexes surface charge identification by Zetasizer and selection of the optimal concentration of solution for conjugation}

The positive surface charge was detected by Zetasizer and also by electrophoresis method on prepared NL and FeNP (on pure entities, non-conjugated with any plasmid). The addition of the different amount of the DNA plasmid to the conjugation solution underwent in $0,5 \mathrm{ml}$ plastic microtube in thermostatic shaker $\left(37^{\circ} \mathrm{C}, 120\right.$ $\mathrm{rpm})$, the mixture of different concentration of plasmid versus constant concentration of nano-entities caused different adhesivity of plasmid NL or FeNP, all variants of concentration $(10,20,40 \mathrm{ng} / \mathrm{\mu L}$ of plasmid and 5 $\mu \mathrm{g} / \mu \mathrm{L}$ of FeNP respectively $0,5 \mu \mathrm{g} / \mu \mathrm{L}$ of $\mathrm{NL}$ ) displayed that the final state of conjugation is almost stable formed in all variants of solution during the first 10 minutes. This fact gives possibility to apply plasmid and remodify the originally nano-entities to complexes covered by significant amount of plasmids in very short time. The most important information from electrophoresis data is quantification of relative and absolute amount of effectively binding plasmid versus resting non-bound plasmid, the data are represented on Figure 1 (conjugation with liposomes) and Figure 2 (conjugation with nanoparticles).

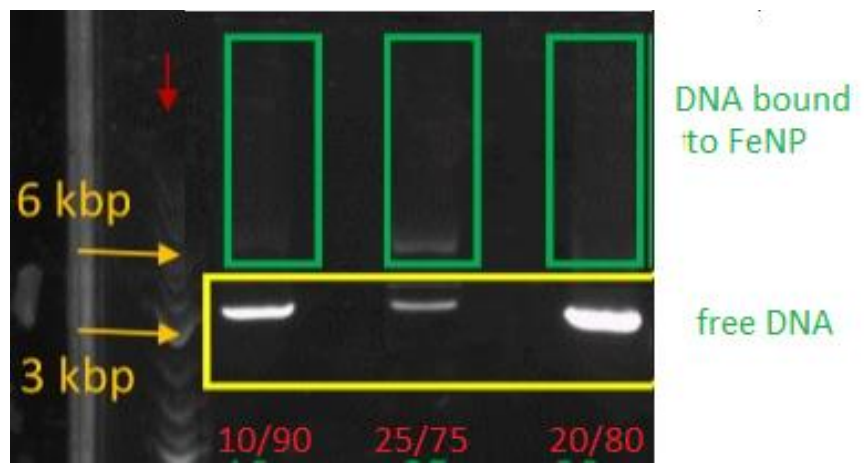

Figure 1 Effectivity of plasmid-FeNP complex creation in mixture tube. Mixed samples (from left to right variant 10,20 or $40 \mathrm{ng} / \mathrm{\mu L}$ of plasmid in conjugation solution) were transpippeted to gel and fractions were measured after $30 \mathrm{~min}$ of migration on gel electrophoresis (110V, arrow means direction of field to anode).

UV scan and Kodak software visualized bound / free fraction of DNA plasmid.

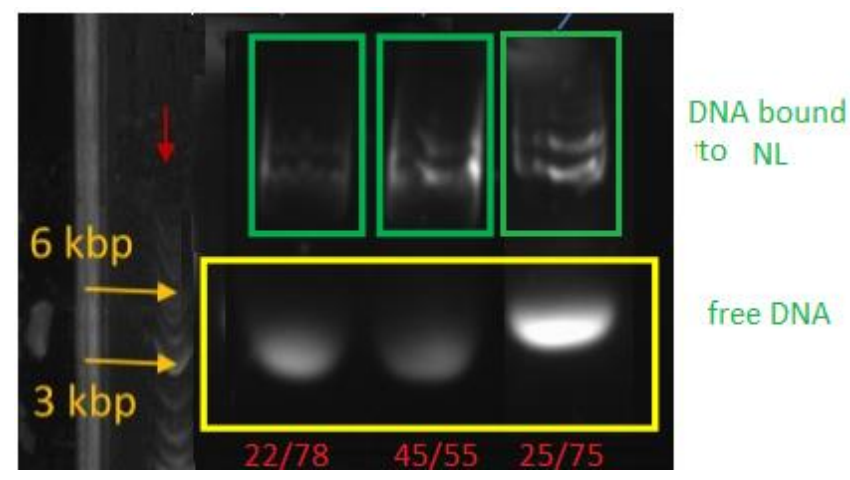

Figure 2 Effectivity of plasmid-NL complex creation in mixture tube. Mixed samples (from left to right variant 10,20 or $40 \mathrm{ng} / \mathrm{\mu L}$ of plasmid in conjugation solution) were transpippeted to gel and fractions were measured after $30 \mathrm{~min}$ of migration on gel electrophoresis (110V, arrow means direction of field to anode). UV scan and Kodak software visualized bound / free fraction of DNA plasmid. 
The surface charge detected in DMEM medium by Zetasizer was $-5.3 \mathrm{mV}$ for plasmid-FeNP complex (variant $20 \mathrm{ng} / \mu \mathrm{L}$ ) and $-1.1 \mathrm{mV}$ for plasmid-NL complex (the variant $20 \mathrm{ng} / \mu \mathrm{L}$ )

\subsection{The test of the final transfection effectivity on the live cells}

Both types of optimized "Trojan horses" (complex based on liposomes or nanoparticles) were tested on cell cultures (addition of previously prepared plasmid-particle complex to DMEM at $37^{\circ} \mathrm{C}$ and $5 \% \mathrm{CO} 2$ atmosphere of the lab incubator, absolute plasmid-particle concentration in solution was adjusted to $0,8 \mathrm{ng} / \mathrm{\mu L}$ in all finally comprised variant). The final GFP positive cells (48 hours after transfection) are describe in Table 2, the representative microscopically scans of cells are on Figure $\mathbf{3}$.

Table 2 Transfection variants and effectivity on live cells

\begin{tabular}{|l|l|l|}
\hline Transfection variant & Plasmid-NL complex & Plasmid-FeNP \\
\hline Neonatal cardiomyocytes & $5.5 \pm 3.1 \%$ & $11.7 \pm 5.5 \%$ \\
\hline Adult cardiomyocytes & $21.5 \pm 8.5 \%$ & $12,2 \pm 9,5 \%$ \\
\hline
\end{tabular}
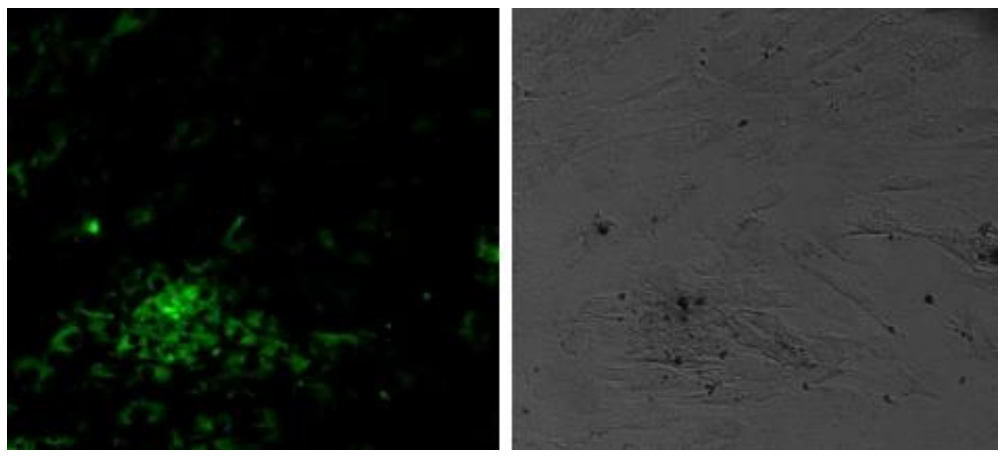

Figure 3 Illustration of microscopically evaluation of neonatal cardiomyocytes transfection and visibility of GFP (variant plasmid-NL). Fluorescence mode exc.490/ em. 520nm (left), the same field of view visualized by phase contrast mode (right).

The very actual preliminary data also illustrated the possibility of higher effectivity of invasion NL or FeNP complexes to the cardiac cells, if the altering electromagnetic field is applied on the cell samples (data not shown), optimizing of the electromagnetic field and its biocompatibility with muscle cells and covering tissue was stared in our parallel project [1].

\section{CONCLUSION}

Our investigation has two basic outputs. The complex zeta potential analysis of cells and entities for gene delivery (cardiomyocytes and nanoparticles or nanolyposomes) has been identified using zetapotential mode of standard DLS machine. The amount of the bound DNA on final "Trojan nanosystems" and charge profile of these nano-systems was adjusted and the optimised variant was used for pilot transfection experiments on cardiac cells. Transfection effectivity was $5-20 \%$, however the methods have potential to be upgraded by additive electromagnetic field which accelerate invasion of charged complex into the cells.

\section{ACKNOWLEDGEMENTS}

The project was supported by Ministry of Education, Youth and Sports of Czech Rep. (project "FIT" CZ.02.1.01/0.0/0.0/15003/0000495) and by Ministry of Industry of Czech Rep. - project FV20422 and project TACR FW01010106 respectively. 


\section{REFERENCES}

[1] HANAKOVA, L., PRUCHA, J., SOCHA, V., ŠTENGL, M., VAN BERGH, S. Effect of High-Induction Magnetic Stimulation on Complex Heart Rate Variability of Sus Scrofa Domesticus under General Anesthesia. Appl. Sci. [online]. 2020, vol. 10, p. 589. Available from: https://doi.org/10.3390/app10020589

[2] BONDAR, O. V., SAIFULLINA, D.V, SHAKHMAEVA, I. I., MAVLYUTOVA, I.I., ABDULLIN, T.I. "Monitoring of the zeta potential of human cells upon reduction in their viability and interaction with polymers." Acta Naturae (англоязычная версия). 2012, vol. 4, no. 1, pp. 80-83

[3] SKOPALIK, J., PASEK, M., RYCHTARIK, M., KORISTEK, Z., GABRIELOVA, E., SCHEER, P., KLABUSAY, M. Formation of cell-to-cell connection between bone marrow cells and isolated rat cardiomyocytes in a cocultivation model. Journal of Cell Science \& Therapy. 2014, vol. 5, no. 5, pp. 1-8.

[4] BÉBAROVÁ, M., MATEJOVIČ, P., PÁSEK, M., HOŘÁKOVÁ, Z., HOŠEK, J., ŠIMURDOVÁ, M., ŠIMURDA, J., 2016. Effect of ethanol at clinically relevant concentrations on atrial inward rectifier potassium current sensitive to acetylcholine. Naunyn-Schmiedeberg's archives of pharmacology. 2016, vol. 389, no.10, pp.1049-1058.

[5] SKOPALIK, J., POLAKOVA, K., HAVRDOVA, M., JUSTAN, I., MAGRO, M., MILDE, D., KNOPFOVA, L., SMARDA, J., POLAKOVA, H., GABRIELOVA, E., VIANELLO, F. Mesenchymal stromal cell labeling by new uncoated superparamagnetic maghemite nanoparticles in comparison with commercial Resovist-an initial in vitro study. International journal of nanomedicine. 2014, vol. 9, p.5355. 